\title{
INDIAN TREATIES AND THE SURVIVAL OF THE GREAT LAKES
}

\author{
Wenona T. Singel \\ Matthew L.M. Fletcher"* \\ 2006 MICH. ST. L. REV. 1285
}

TABLE OF CONTENTS

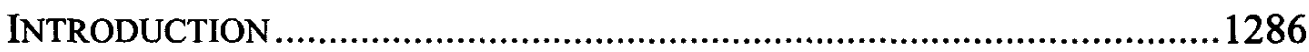

I. INDIAN TREATIES AND NATURAL RESOURCE PROTECTION ................1288

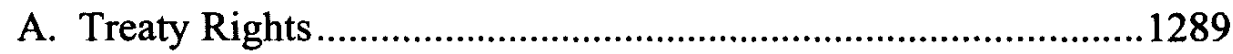

B. Great Lakes Indian Treaties...................................................1291

II. INCORPORATING INDIAN TRIBES AND INDIAN TREATIES .....................1293

A. Indian Treaties in Federal and State Litigation............................1293

B. Indian Tribes as Stakeholders in International Compacting

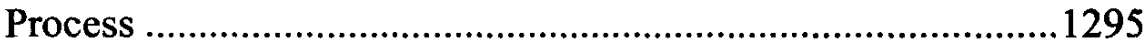

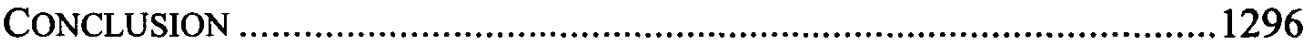

The single most important defining element of the place we live, what makes this place unique in the entire world, is the Great Lakes and the waters that recharge these lakes from the springs, creeks, streams and rivers that make up this vast watershed. We speak for and honor the waters as the life-blood of our Mother Earth as an integral part of our traditional spirituality. As Native Nations we utilize these waters to define our boundaries, transport ourselves and trade goods, fish for our food and commerce, and enjoy their value for recreation and a strong economy.

-Frank Ettawageshik ${ }^{1}$

* Assistant Professor, Michigan State University College of Law; Associate Director, Indigenous Law and Policy Center; Appellate Judge and Enrolled Member, Little Traverse Bay Bands of Odawa Indians. This paper was prepared for The Great Lakes Water Basin: International Law and Policy Crossroads Conference held by the MSU Institute for Trade in the Americas, December 1-2, 2006. We thank Kevin Kennedy and Chris Bzdok for the invitation to participate in the conference.

** Assistant Professor, Michigan State University College of Law; Director, Indigenous Law and Policy Center; Appellate Judge, Hoopa Valley Tribe, Pokagon Band of Potawatomi Indians, and Turtle Mountain Band of Chippewa Indians; Enrolled Member, Grand Traverse Band of Ottawa and Chippewa Indians. 


\section{INTRODUCTION}

Anishinaabe elder Basil Johnston wrote that the waters of the Great Lakes gave the Anishinaabek a steady-if not "boundless"- source of food. ${ }^{2}$ "[T]here were so many fish that the waters were said to be alive with fish." ${ }^{\text {"3 }}$ Anishinaabe storytellers claimed that "when a school of fish passed in the shallows or over a shoal, the bottom of the lake could not be seen." "The waters of lakes, rivers and seas were generous, abundant beyond saying." But in the early years of the twenty-first century, the inland seas known as the Great Lakes are all but depleted. ${ }^{6}$ Fish harvests by sports fishers, commercial fishers, and Indian tribes are at all-time lows. ${ }^{7}$ And what fish are harvested cannot be consumed in great (or subsistence) quantities because of contamination by pollutants such as mercury and dioxin. ${ }^{8}$ Tribal fishers, after decades of political, legal, and often violent conflict, persevered over their adversaries to preserve treaty fishing rights only to be faced with the prospect of "dip[ping their] nets into the water and [having them come up] empty." "[T]hreats currently facing Great Lakes fisheries include invasive species, loss of native species, habitat destruction or degradation, water withdrawals, and pollution."10

1. Frank Ettawageshik, Protecting the Life-Blood of Mother Earth, BEDOHGEIMO (Office of the United States Attorney for the Western District of Michigan, Grand Rapids, Mich.), Winter 2004-05, at 3, http://www.usdoj.gov/usao/miw/nativenews/4newsletter.pdf.

2. Basil H. Johnston, Honour Earth Mother: Mino-audjaudauH MizzuKUMMIK-QUAE 139 (2003).

3. Id. at 135 .

4. Id.

5. Id. at 136; see also RICHARD WHITE, THE MIDDLE GROUND: INDIANS, EMPIRES, AND REPUBLICS IN THE GREAT LAKES REGION, 1650-1815 43-44 (1991) (noting that the fisheries were a critical source of food for Great Lakes Indians in the pre-treaty era).

6. Scott Fields, Great Lakes: Resource at Risk, ENVTL. HEALTH PERSP., Mar. 2005, at A165, A167.

7. See, e.g., Brian BREIDERT, IND. DeP'T of NAT. Res., HARVEST OF FisheS from LAKE MICHIGAN DURING 2004 (2005), http://www.in.gov/dnr/fishwild/fish/lkmich/harvest .pdf; N.Y. State DeP'T OF ENVTL. Conservation, BuREaU OF Fisheries 1999/2000 ANN. REP., http://www.dec.state.ny.us/website/dfwmr/fish/argrlake.pdf; GREAT LAKES FISHERY COMM'N, JoINt Strategic Plan for Mgmt. OF Great LaKes Fisheries (1994), http://www.glfc.org/pubs/sglbod.htm (last visited Mar. 29, 2007).

8. See H.M. Chan et al., Impacts of Mercury on Freshwater Fish-Eating Wildlife and Humans, 9 Hum. \& ECOLOGICAL RISK ASSESSMENT 867, $877-79$ (2003); Michael Gilbertson \& David O. Carpenter, An Ecosystem Approach to the Health Effects of Mercury in the Great Lakes Basin Ecosystem, 95 ENVTL. RES. 240, 243 (2004); Lake Ontario's Dioxin Level Still High and Bottom-Feeder the Likely Culprit, TORONTO STAR, July 13, 1996, at C6.

9. See United States v. Washington, 506 F. Supp. 187, 203 (W.D. Wash. 1980) ("Were this trend to continue, the right to take fish would eventually be reduced to the right to dip one's net into the water ... and bring it out empty.").

10. Jeffrey W. Henquinet \& Tracy Dobson, The Public Trust Doctrine and Sustainable Ecosystems: A Great Lakes Fisheries Case Study, 14 N.Y.U. ENVTL. L.J. 322, 339 
Federal and state statutory and regulatory protections do not appear to be the answer to preventing the ongoing calamity in the waters of the Great Lakes. ${ }^{11}$ To fill in the gap, environmental advocates and scholars devote much of their attentions to the public trust doctrine, ${ }^{12}$ first articulated in this context by Joseph Sax. ${ }^{13}$ Little attention is devoted to the insights of Indian tribes or to the potential legal benefits of invoking Indian treaty rights. ${ }^{14}$ The Supreme Court has long affirmed the supremacy of Indian treaty provisions, ${ }^{15}$ and while the Court's interpretation of some treaties has been cramped at best ${ }^{16}$ the Great Lakes and Pacific Northwest treaties have been interpreted in a manner that suggests there is room to provide for protection of major water bodies. ${ }^{17}$

The authors propose to incorporate Indian treaty jurisprudence into the strategy for saving the Great Lakes. The interests of the parties tend to be the same: the preservation of the resource. Indian treaties negotiated by Indian peoples that relied on water as a means of survival-economic, cultural, and political-provide a potential (and as yet untested) legal tool for the preservation of major water bodies such as the Great Lakes. Incorpora-

(2006); see also id. at 341 ("Pollution poses problems for fisheries, both because of its destructive effects on the ecosystem and its contamination of fish. A right to fish is seemingly worthless without the ability to eat that fish ....").

11. Professor Noah Hall's theory of "cooperative horizontal federalism" would be a giant leap forward. See generally Noah D. Hall, Toward a New Horizontal Federalism: Interstate Water Management in the Great Lakes Region, 77 U. COLo. L. REV. 405 (2006).

12. See generally Alexandra B. Klass, Modern Public Trust Principles: Recognizing Rights and Integrating Standards, 82 NOTRE DAME L. REV. 699 (2006) (summarizing the development of the public trust doctrine); Federico M. Cheever, Comment, $A$ New Approach to Spanish and Mexican Land Grants and the Public Trust Doctrine: Defining the Property Interest Protected by the Treaty of Guadalupe-Hidalgo, 33 UCLA L. REv. 1364, 1364-69 (1986) (discussing the origins of the public trust doctrine); Kristen A. Carpenter, $A$ Property Rights Approach to Sacred Sites Cases: Asserting a Place for Indians as Nonowners, 52 UCLA L. REV. 1061, 1124 (2005) (arguing for the application of the public trust doctrine in tribal sacred sites litigation).

13. Joseph L. Sax, The Public Trust Doctrine in Natural Resource Law: Effective Judicial Intervention, 68 MiCH. L. REV. 473 (1970).

14. Richard Delgado, Our Better Natures: A Revisionist View of Joseph Sax's Public Trust Theory of Environmental Protection, and Some Dark Thoughts on the Possibility of Law Reform, 44 VAND. L. REV. 1209, 1220-21 (1991) (arguing that the public trust doctrine foreclosed any possible solution that could be developed by American Indians).

15. See, e.g., Winters v. United States, 207 U.S. 564, 575-77 (1908); United States v. Winans, 198 U.S. 371, 380-84 (1905).

16. See, e.g., South Dakota v. Yankton Sioux Tribe, 522 U.S. 329 (1998).

17. See Minnesota v. Mille Lacs Band of Chippewa Indians, 526 U.S. 172 (1999); Washington v. Washington State Commercial Passenger Fishing Vessel Ass'n, 443 U.S. 658 (1979); Lac Courte Oreilles Band of Lake Superior Chippewa Indians v. Voigt, 700 F.2d 341 (7th Cir. 1983); United States v. Michigan, 471 F. Supp. 192 (W.D. Mich. 1979); United States v. Washington, 459 F. Supp. 1020 (W.D. Wash. 1978), aff'd sub nom. Puget Sound Gillnetters Ass'n v. U.S. Dist. Court, 573 F.2d 1123 (9th Cir. 1978); United States v. Washington, 384 F. Supp. 312 (W.D. Wash. 1974), aff'd, 520 F.2d 676 (9th Cir. 1975). 
tion of Indian treaties may also help to alleviate the systematic limitations of the public trust doctrine, as identified by Richard Delgado. ${ }^{18}$ Moreover, incorporation of the American Indian tribes and Canadian First Nations into the discussion is absolutely mandatory in order to reach true environmental justice. $^{19}$

This Article proposes a preliminary strategy toward the end of preserving the Great Lakes for the next seven generations and beyond, if possible. Part I introduces a short history of Indian treaty law in the context of natural resource use and conservation. Part I also provides a short history and description of some of the Great Lakes Indian treaties and treaty litigation. Part II justifies including Indian tribes in any potential solution to the Great Lakes problem. Part III provides the preliminary framework for a Great Lakes solution that involves Indian tribes.

\section{INDiAn TREATIES AND NATURAL RESOURCE PROTECTION}

The litigation of Indian treaties has a rich and varied history. ${ }^{20}$ Treaty rights litigation also rose in prominence around the same time as Joe Sax's seminal 1970 article on the public trust doctrine $e^{21}$ and the concomitant rise of the environmental movement, but Indians and Indian tribes (often with the cooperation of the United States as a co-plaintiff) have been litigating and winning significant treaty cases since at least 1905's United States $v$.

18. Delgado, supra note 14 , at 1213-18.

19. The Long Lake No. 58 First Nation Reserve in Canada has been devastated by a water diversion project (Long Lac and Ogoki diversion) into the Great Lakes. See PeTER ANNIN, THE GREAT LAKES WATER WARS 121 (2006).

20. See generally ROBERT DOHERTY, DISPUTED WATERS: NATIVE AMERICANS AND THE GREAT LAKES FISHERY (1990) (describing the conflicts over Indian treaty rights in northwest lower Michigan); VINE DELORIA, JR., INDIANS OF THE PACIFIC NORTHWEST: From the COMING OF THE White MAN to tHe Present Day 145-97 (1977) (describing the conflicts over Indian treaty fishing rights in the Pacific Northwest); FISH IN THE LAKES, WILD Rice, and Game in Abundance: Testimony on Behalf of Mille lacs OJibwe Hunting AND FisHING RighTS (James M. McClurken et al. eds., 2000) [hereinafter FISH, RICE, AND GAME] (compiling expert reports and testimony in relation to Minnesota v. Mille Lacs Band of Chippewa Indians, 526 U.S. 172 (1999)); Francis PaUl PrUCha, AMERICAN INDIAN TREATIES: THE History OF A POLITICAL ANOMALY 409-28 (1994) (describing treaty rights activism); Ronald N. Satz, Chippewa Treaty Rights: The Reserved Rights of Wisconsin's Chippewa Indians in Historical Perspective, TRANSACTIONS WIS. ACAD. SCI., ARTS, \& LETTERS, 1991, at 1, 91-128 (describing the conflicts over Indian treaty rights in Wisconsin); George Weeks, Mem-Ka-WeH: Dawning of the Grand Traverse Band of OtTaWa and CHIPPEWA INDIANS 41-64 (1992) (describing the conflicts over Indian treaty rights in northwest lower Michigan).

21. See Sax, supra note 13. 
Winans. $^{22}$ Most treaty rights litigation involves the particular rights of certain property owners, namely Indians and Indian tribes.

\section{A. Treaty Rights}

The first major Supreme Court case regarding Indian treaty rights held that the rights contained in Indian treaties were not grants from the federal government, but a "reservation of those [rights] not granted."23 Treaty fishing rights, the Court concluded, "were not much less necessary to the existence of the Indians than the atmosphere they breathed."24 The Court noted that Indians and Indian tribes retained rights to fish off the reservation as well, and although limited to some extent, the Court described them as a "servitude" or "easement" upon lands off the reservation alienated by the federal government to non-Indians. ${ }^{25}$ The Court noted that both on- and offreservation rights had to be recognized in order to "give effect to the treaty."26 Three years later, the Court held that an Indian treaty implicitly reserved rights to water that the tribe had ceded, otherwise the treaty would have left the reservation a "barren waste."27 Once again, the Court looked to the purpose of the treaty and concluded that the Indian leaders would never have agreed to a treaty that would destroy the land that they retained. ${ }^{28}$

Indian treaty interpretation by federal courts focuses on two very important issues. First, the courts review the original purpose of the treaty. ${ }^{29}$ This analysis often is controlled by the canon of Indian treaty construction, ${ }^{30}$ which holds that ambiguities in Indian treaty language should be interpreted in accordance with the way the Indians that executed the treaty understood it. $^{31}$ Second, the courts look to see if the treaty has been abrogated in any way, either completely or partially. ${ }^{32}$ If the treaty has been abrogated, even

22. 198 U.S. 371 (1905). See generally 1 WILlIAM H. RODGERS, JR., ENVIRONMENTAL LAW IN INDIAN COUNTRY $\S 1.2$, at 27-32 (2005) (providing the back story in the Winans decision).

23. Winans, 198 U.S. at 381.

24. Id.

25. Id. at 381,384 .

26. Id. at 381 .

27. Winters v. United States, 207 U.S. 564, 577 (1908).

28. Id. at 576-77.

29. See, e.g., id.

30. See generally COHEN's HANDBOOK OF FEDERAL INDIAN LAW $§ 2.02$ at 119-28 (Nell Jessup Newton et al. eds., 2005) [hereinafter FEDERAL INDIAN LAw].

31. See Minnesota v. Mille Lacs Band of Chippewa Indians, 526 U.S. 172, 196 (1999); Tulee v. Washington, 315 U.S. 681, 684-85 (1942); United States v. Winans, 198 U.S. 371, 380-81 (1905).

32. See, e.g., Lone Wolf v. Hitchcock, 187 U.S. 553, 566 (1903). 
partially, often courts will ignore the purpose of the treaty and will refuse to apply the canon of construing Indian treaty language. ${ }^{33}$

Assuming an Indian treaty has not been abrogated, courts are more likely to find that the tribal resource rights remain extant. These resource rights include without limitation: fisheries, ${ }^{34}$ hunting, ${ }^{35}$ cultivation or gathering, ${ }^{36}$ and water rights. ${ }^{37}$ They survive Congressional termination of Indian tribes. ${ }^{38}$ The resource rights are strongest on Indian lands ${ }^{39}$ but, as Winans suggests, they extend off the reservation as well ${ }^{40}$ and constitute a form of legal and enforceable servitude on all lands ceded by the tribes in the treaty. ${ }^{41}$ These rights are powerful; they can trump private property rights, ${ }^{42}$ state regulation, ${ }^{43}$ and even state criminal laws. ${ }^{44}$ The limitations on Indian treaty rights tend to be pragmatic limitations related to resource conservation issues where the courts read conservation mandates into the Indian treaties in the Great Lakes basin and the Pacific Northwest. ${ }^{45}$ As a result, the courts find that the states and the tribes should be co-managers of the resource, leading to the establishment of resource conservation agreements and inter-sovereign cooperation. ${ }^{46}$

33. See, e.g., South Dakota v. Yankton Sioux Tribe, 522 U.S. 329, 348 (1998); Hagen v. Utah, 510 U.S. 399, 422-24 (1994) (Blackmun, J., dissenting).

34. See, e.g., Mille Lacs Band, 526 U.S. at 175-76; Washington v. Wash. State Commercial Passenger Fishing Vessel Ass'n, 443 U.S. 658, 684-85 (1979); Lac Courte Oreilles Band of Lake Superior Chippewa Indians v. Voigt, 700 F.2d 341, 343-44, 365 (7th Cir. 1983); United States v. Michigan, 471 F. Supp. 192, 278-81 (W.D. Mich. 1979); United States v. Washington, 459 F. Supp. 1020, 1032 (W.D. Wash. 1978); United States v. Washington, 384 F. Supp. 312, 332-33 (W.D. Wash. 1974). See generally RoDGERS, supra note $22, \S 1.2$, at $25-61$ (describing treaty fishing rights litigation).

35. See, e.g., Mille Lacs Band, 526 U.S. at 175-76; Menominee Tribe of Indians v. United States, 391 U.S. 404, 406 (1968); Mitchel v. United States, 34 U.S. 711,746 (1835).

36. See, e.g., United States v. Aanerud, 893 F.2d 956, 961 (8th Cir. 1990).

37. See, e.g., Winters v. United States, 207 U.S. 564 (1908); FEDERAL INDIAN LAW, supra note $30, \S 19.02$, at 1171-73.

38. See Menominee Tribe, 391 U.S. at 412-13.

39. See FEDERAL INDIAN LAW, supra note 30, § 18.03[2], at 1126-28.

40. See, e.g., Mille Lacs Band, 526 U.S. at 201-02; Organized Village of Kake v. Egan, 369 U.S. 60, 76 (1962).

41. See Grand Traverse Band of Ottawa \& Chippewa Indians v. Dir., Mich. Dep't of Natural Res., 141 F.3d 635, 639 (6th Cir. 1998); FEDERAL INDIAN LAw, supra note 30, at 1123. A Fifth Amendment right may attach to these servitudes or easements. See Muckleshoot Indian Tribe v. Hall, 698 F. Supp. 1504, 1510 (W.D. Wash. 1988).

42. See, e.g., Grand Traverse Band, 141 F.3d at 639-41.

43. See, e.g., New Mexico v. Mescalero Apache Tribe, 462 U.S. 324, 325 (1983).

44. See, e.g., People v. LeBlanc, 248 N.W.2d 199, 202 (Mich. 1976).

45. Puyallup Tribe v. Dep't of Game, 391 U.S. 392, 398 (1968); United States v. Michigan, 653 F.2d 277, 279 (6th Cir. 1981); United States v. Washington, 520 F.2d 676, 686 n.4 (9th Cir. 1975); RoDGERS, supra note 22, $\S 1.3$, at 61-85.

46. See, e.g., Consent Decree, United States v. Michigan at 2, No. 2:73 CV 26 (W.D. Mich. Aug. 8, 2000), http://www.1836cora.org/pdf/2000consentdecree.pdf. 
Consequently, tribal treaty rights are a powerful environmental law tool. In the words of Professor Bill Rodgers:

[Indian] treaties have the look, touch, and feel of a conservation easement. The fishing right is place-based, which means it is dependent upon protecting geography. It is expressed as a property interest, which means it is disposable if at all only by choice of the owner. It is owned by Native people for whom sale is an anathema. $^{47}$

\section{B. Great Lakes Indian Treaties}

The Anishinaabek on the United States side of the Great Lakes entered into dozens of treaties with the federal government in the eighteenth and nineteenth centuries, ceding their claims and interests to millions of acres of land in exchange for certain concessions by the United States but reserving the authority and capacity to continue to live as they chose in limited territories. ${ }^{48}$ Great Lakes Indian people retained certain usufructuary rights over ceded lands and waters to hunt and fish for sustenance and commerce. ${ }^{49}$ In fact, the Anishinaabek would not have agreed to enter into any of these treaties unless the treaty was understood to have preserved their right to hunt and fish on ceded lands and waterways, subject to certain pragmatic limitations, and to fish in the Great Lakes without limitation. ${ }^{50}$ In a similar fashion, Indian nations throughout the United States that depended upon fish for sustenance and commerce understood their treaties to mean that they could continue to hunt and fish on ceded lands. ${ }^{51}$ And American treaty negotiators knew full well that Indian treaty negotiators sought to preserve the ability to hunt and fish on ceded lands and waters. ${ }^{52}$

The historical context of the Michigan Indian treaty negotiations is critical to understanding and applying them. The lead American treaty ne-

47. RODGERS, supra note $22, \S 1.3$, at 73 .

48. E.g., Treaty with the Chippewa of Saginaw, Swan Creek, and Black River, 14 Stat. 637 (1864); Treaty of Detroit, 11 Stat. 621 (1855); Treaty with the Chippewa at LaPointe, 10 Stat. 1109 (1854); Treaty with the Chippewa at LaPointe, 7 Stat. 591 (1842); Treaty of Washington, 7 Stat. 491 (1836); Treaty of Greenville, 7 Stat. 49 (1795).

49. See, e.g., Menominee Tribe of Indians v. United States, 391 U.S. 404, 405-07 (1968); United States v. Michigan, 471 F. Supp. 192, 279 (W.D. Mich. 1979); People v. LeBlanc, 248 N.W.2d 199, 204-05 (Mich. 1976).

50. See, e.g., James M. McClurken, The 1837 Treaty of St. Peters Preserving the Rights of the Mille Lacs Ojibwa to Hunt, Fish, and Gather: The Effect of Treaties and Agreements Since 1855, in FISH, RICE, AND GAME, supra note 20, at 327, 336-37 (testifying that the major purpose of the treaty negotiation from the tribal side was to preserve access to natural resources).

51. E.g., Charles E. Cleland, Preliminary Report of the Ethnohistorical Basis of the Hunting, Fishing, and Gathering Rights of the Mille Lacs Chippewa, in FISH, RICE, AND GAME, supra note 20, at 1,111 (testifying that the Indians "would have understood that the duration of the [usufruct] guarantee extended indefinitely into the future").

52. E.g., McClurken, supra note 50, at 337. 
gotiator, Henry Schoolcraft, recognized that the fisheries of the Great Lakes alone could support the existence of Indian tribes on the shores. ${ }^{53}$ Indian people depended a great deal on the Great Lakes fisheries with some bands eating fish as 75 percent of their diet by $1850 .^{54}$ "Before 1830 commerce in fish had been managed almost entirely by the Indians. Early traders and commercial fishermen sought and paid for tribal permission, and thus implicitly recognized the Indian right to the Lakes' fisheries."ss But by the 1830 s, white commercial trapping and hunting had all but eradicated the game in the upper portions of Michigan. ${ }^{56}$ And by the $1850 \mathrm{~s}$, the fisheries were depleted, leading to the creation of the state's first conservation agencies. $^{57}$

In this historical context, several Michigan Odawa and Ojibwe bands entered into a treaty in 1836 with the federal government that preserved the ability and authority of Indian people to hunt and fish in ceded territories "until the land is required for settlement" and in the Great Lakes forever. Judge Fox held in 1979:

The language contained in Article Thirteenth of the Treaty of 1836, by its own terms could not have limited the Indians' right to fish in the waters of the Great Lakes because these large bodies of water could not possibly be settled by homes, barns and tilled fields. While the Indians might have been willing to give up their right to hunt on various parcels of land as that land became occupied with settlers, the vital right to fish in the Great Lakes was something that the Indians understood would not be taken from them and, indeed, there was no need to do so. The western movement of non-Indian settlers could be accommodated without requiring the Indians to relinquish their aboriginal and treaty rights to fish. While the United States has the power to abrogate treaties by subsequent treaty or statute, it must do so expressly and emphatically. No such abrogation of the reserved treaty right to fish can be found. ${ }^{59}$

53. Robert H. Keller, An Economic History of Indian Treaties in the Great Lakes Region, AM. INDIAN J., Feb. 1978, at 2, 12.

54. Id.

55. Id.

56. Id. at 13 .

57. Id.

58. Treaty with the Ottawa, Etc., art. 13, 7 Stat. 491 (1836). See generally James M. McClurken, Ottawa Adaptive Strategies to Indian Removal, MiCH. HIST. REv., Spring 1986, at 29,35 (describing the major points of the 1836 treaty, including permanent title to lands); Helen Hornbeck Tanner, Mapping the Grand Traverse Indian Country: The Contributions of Peter Dougherty, MICH. HIST. REv., Spring 2005, at 45, 63-64 (same); cf. Benjamin Ramirez-Shkwegnaabi, The Dynamics of American Indian Diplomacy in the Great Lakes Region, 27 AM. INDIAN CULTURE \& RES. J. 53, 71 (2003) (same, in relation to 1855 Treaty of Washington, 11 Stat. 621 (1855)). See generally Keweenaw Bay Indian Cmty. v. Naftaly, 452 F.3d 514, 525-26 (6th Cir. 2006), cert. denied, 127 S. Ct. 680 (2006).

59. United States v. Michigan, 471 F. Supp. 192, 253 (W.D. Mich. 1979). 
The Anishinaabe treaty negotiators "fully appreciated the treaty's provision for usufructuary rights of the natural resources in their territory." Federal courts have recognized that the rights of the Michigan Anishinaabek are "unabridged, aboriginal, tribal right[s] to fish derived from thousands of years of occupancy and use of the fishery of the waters of Michigan."61 The Sixth Circuit even held that treaty fishers must be given access to municipal mooring points along Lake Michigan. ${ }^{62}$

The impact of treaty rights litigation in the Great Lakes states has been nothing short of phenomenal. The Supreme Court's decision in Minnesota v. Mille Lacs Band of Chippewa Indians upheld the off-reservation usufructuary rights of the Minnesota Chippewa people to hunting, fishing, gathering, and cultivating to the exclusion of state laws and regulation. ${ }^{63}$ Federal courts in Wisconsin upheld Wisconsin Indian treaty rights in Lac Courte Oreilles Band of Lake Superior Chippewa Indians v. Wisconsin. ${ }^{64}$ And, of course, federal courts recognized the right of Michigan Indian tribes to fish in Great Lakes waters in accordance with the Treaty of $1836 .{ }^{65}$

\section{INCORPORATING INDIAN TRIBES AND INDIAN TREATIES}

The authors offer two non-mutually exclusive possibilities for Great Lakes advocates. First, advocates could seek to incorporate Indian treaties into federal environmental law. ${ }^{66}$ Second, they should include Indian perspectives in the dialogue leading to interstate and international agreements. ${ }^{67}$

\section{A. Indian Treaties in Federal and State Litigation}

The authors propose incorporating Indian treaty rights into the discussion as a means of preserving the Great Lakes. Indian tribes have not yet begun litigating over the broader issues of the Great Lakes-pollution, de-

60. McClurken, supra note 58, at 37.

61. United States v. Michigan, 505 F. Supp. 467, 472 (W.D. Mich. 1980).

62. Grand Traverse Band of Ottawa \& Chippewa Indians v. Dir., Mich. Dep't of Natural Res., 141 F.3d 635, 638-39 (6th Cir. 1998).

63. 526 U.S. 172, 175-76 (1999). See generally FISH, RICE, AND GAME, supra note 20 (compiling expert reports and testimony in relation to Minnesota v. Mille Lacs Band of Chippewa Indians).

64. 653 F. Supp. 1420, 1435 (W.D. Wis. 1987). See generally Satz, supra note 20 (describing the conflicts over Indian treaty rights in Wisconsin); Charles F. Wilkinson, To Feel the Summer in the Spring: The Treaty Fishing Rights of the Wisconsin Chippewa, 1991 WIS. L. REV. 375.

65. United States v. Michigan, 471 F. Supp. 192, 253 (W.D. Mich. 1979).

66. See infra Part II.A.

67. See infra Part II.B. 
clining water levels, ${ }^{68}$ water exports, invasive species, and the rest of the plethora of problems facing the future of the Lakes-focusing instead on establishing other tribal rights such as hunting, fishing, gathering, and access rights. Indian tribes and environmental advocacy organizations or other individuals with standing could bring suit, for example, under public trust and treaty rights causes of action. ${ }^{69}$

First, the Great Lakes litigation would be grounded in positive, written law-Indian treaties - with the backing of the Supremacy Clause. ${ }^{70}$ Indian treaties often have been construed as requiring both the federal government and the states to preserve the resource, such as the water levels, stream flows, or other environmental protections. The so-called "Culverts case," an ongoing subproceeding in United States $v$. Washington, offers a legal basis for construing Indian treaties as requiring governments to preserve the resource. In that proceeding, the tribes sued the State of Washington over whether the culverts used by the State and local governments were sufficient to preserve in-stream water flows to the extent necessary to allow for anadromous fish ${ }^{71}$ to reach their spawning habitat. ${ }^{72}$ Such a theory could work in the Great Lakes as well, with numerous Great Lakes Indian treaties offering language and history to support the theory.

Second, Indian treaty rights tend to trump state and private property rights without a takings concern. It is true that the public trust doctrine also is construed in this manner, but in reality it is a common law doctrine subject to the divestiture of its properties by the courts. ${ }^{73}$

68. The Michigan Ottawa tribes brought a federal claim against a water bottling company with a well in central lower Michigan that had the potential to take enough water from the watershed to make Lake Michigan water levels drop, but the tribes did not raise a treaty claim. See Little Traverse Bay Bands of Odawa Indians v. Great Spring Waters of Am., Inc., 203 F. Supp. 2d 853, 854 n.2 (W.D. Mich. 2002). A parallel state court case is pending before the Michigan Supreme Court. Michigan Citizens for Water Conservation v. Nestlé Waters N. Am. Inc., 709 N.W.2d 174, 188-92 (Mich. Ct. App. 2005) (describing trial court's findings of facts in parallel state court case), leave granted to file briefs amicus curiae, 722 N.W.2d 422 (Mich. 2006).

69. This is not a particularly original proposal. Professor Kristen Carpenter persuasively and perspicaciously argued that the public trust doctrine should be used as a means of preserving sacred sites of Indian peoples where treaty rights fail. Carpenter, supra note 12, at 1124 .

70. U.S. CONST. art. VI ("This Constitution, and the laws of the United States which shall be made in pursuance thereof; and all treaties made, or which shall be made, under the authority of the United States, shall be the supreme law of the land ....').

71. Fish that migrate from saltwater to fresh water to spawn.

72. The Culverts case is scheduled to go to trial in the summer of 2007. See Fish, Wildlife \& Parks Division, Washington State Office of the Attorney General, Significant Cases, http://www.atg.wa.gov/page.aspx?id=1800\#cases (last visited Mar. 29, 2007).

73. Commentators often criticize the public trust doctrine for its apparent hostility to private property rights and lack of basis in the Constitution or statute. See, e.g., George A. Gould, The Public Trust Doctrine and Water Rights, 34 ROCKY MTN. MIN. L. INST. 25-1, 49 
Third, a litigation strategy involving Indian treaties does not foreclose alternate litigation strategies and encourages the development of longerterm solutions for the Great Lakes. Litigation over the interpretation of Indian treaties necessarily requires a deep understanding of what the tribal treaty negotiators understood the treaties to mean. ${ }^{74}$ Richard Delgado's withering critique of the public trust doctrine-that the doctrine preempted the development of more alternative and experimental means of preserving the environment such as ecofeminism and other more holistic worldviews $^{75}$ - would be answered, in part, by strategy and policy that looks at the environment the way Indian people look at it, which, by definition, is far more open to unusual and progressive alternatives.

One possible weakness to this strategy is that the treaties tend only to cover waters that are in direct contact with the territories ceded in the treaties. For example, in the 1836 Treaty of Washington several Ojibwe and Odawa bands ceded approximately half of the Lower Peninsula and half of the Upper Peninsula of Michigan. ${ }^{76}$ The United States $v$. Michigan litigation resulted in a preservation of the fishing right in three of the Great Lakes (Michigan, Superior, and Huron), ${ }^{77}$ but did not cover the remainder of the Great Lakes or their Canadian side. Moreover, there are more actors and stakeholders than the states, the federal government, and American Indian tribes. No litigation strategy is complete without considering additional avenues of redress.

\section{B. Indian Tribes as Stakeholders in International Compacting Process}

In November 2004, over 100 American Indian tribes and Canadian First Nations met at Sault Ste. Marie, Michigan to discuss means of cooperating in the preservation of the Great Lakes. Practically every tribe and nation that sent representatives agreed to an accord promising to cooperate with each other. ${ }^{78}$ While the process of including these sovereign entities

(1988); Richard A. Epstein, The Public Trust Doctrine, 7 CATO J. 411, 417-22, 428-30 (1987); James L. Huffman, Avoiding the Takings Clause Through the Myth of Public Rights: The Public Trust and Reserved Rights Doctrines at Work, 3 J. LAND USE \& ENVTL. L. 171, 204-12 (1987).

74. See Keweenaw Bay Indian Cmty. v. Naftaly, 452 F.3d 514, 525-26 (6th Cir. 2005) (discussing expert ethnohistorical reports explaining how Indians understood an 1854 treaty), cert. denied, $127 \mathrm{~S}$. Ct. 680 (2006).

75. Delgado, supra note 14, at 1213-21.

76. Treaty with the Ottawas, Etc. art. I, 7 Stat. 491 (1836). For a general map of treaty ceded waters, see http://www.1836cora.org/ (last visited Mar. 29, 2007).

77. See Consent Decree, United States v. Michigan at 7-17, No. 2:73 CV 26 (W.D. Mich. Aug. 8, 2000), http://www.1836cora.org/pdf/2000consentdecree.pdf.

78. Tribal and First Nations Great Lakes Water Accord (Nov. 23, 2004) (on file with the authors). 
into the international and state governors' Great Lakes preservation working groups is beginning, ${ }^{79}$ more can and should be done.

The work of tribal leaders such as Frank Ettawageshik, chairman of the Little Traverse Bay Bands of Odawa Indians, on behalf of the Great Lakes is indispensable to the effort. He led the campaign to get the American Indian tribes and the Canadian First Nations together in 2004, testified before the Senate Committee on the Environment and Public Works in $2006,{ }^{80}$ and participated in a groundbreaking cooperative agreement between the tribes of Michigan and the State of Michigan. ${ }^{81}$ According to Chairman Ettawageshik, "inter-governmental and other partnerships allow the parties to achieve public benefits that no one partner could achieve alone." ${ }^{82}$

\section{CONCLUSION}

The survival of the Great Lakes and the continuing viability of Indian treaty rights exist in fascinating juxtaposition. Indian treaty law offers recognition of Indian ownership of interests in public (and in some instances private) lands, waters, and natural resources, enforceable through a tribalfederal government agreement equivalent to a federal statute. Indian treaties are the supreme law of the land but only cover ceded territories and involve limited property rights. Nevertheless, treaty rights must be an important part of the strategy to save the Great Lakes. As Frank Ettawageshik's work to incorporate Indian tribes into the broader discussion as a political matter progresses, discussion of Indian treaty rights will follow. All parties have much to learn from each other.

Father Baraga wrote long ago: "Indians residing on the edges of [the Great $L$ ]akes feed on nothing but fish. ... These lakes are so rich in fish that an Indian commonly takes twelve or fifteen large fish per day." ${ }^{\prime 33}$ Anishinaabe people used the waters of the Great Lakes as an important part of

79. Water Management Working Group, Council of Great Lakes Governors, Summary of Meeting with Tribal and First Nations Representatives (Feb. 1, 2005), http://www.cglg.org/projects/water/docs/MeetingSummaries/2-1-05Tribes-FirstNationsMeet ingSummary.pdf.

80. Great Lakes Regional Collaboration's Strategy to Restore and Protect the Great Lakes, Hearing Before the S. Comm. on Environment and Public Works, 109th Cong. (2006) [hereinafter Ettawageshik Testimony] (statement of Frank Ettawageshik, Chairman, Little Traverse Bay Bands of Odawa Indians), http://epw.senate.gov/109th/Ettawageshik_Testimony.pdf.

81. Intergovernmental Accord Between the Federally Recognized Indian Tribes in Michigan and the Governor of the State of Michigan Concerning Protection of Shared Water Resources (May 12, 2004), http://www.michigan.gov/documents/Accord_91058_7.pdf.

82. Ettawageshik Testimony, supra note 80 , at 8.

83. FREDERIC BARAGA, SHORT History OF THE NORTH AMERICAN INDIANS 121 (Graham A. MacDonald trans., U. Calgary Press 2004) (1837). 
their daily lives. But psychologist Carl G. Jung wrote: "As scientific understanding has grown, so our world has become dehumanized. ... [Peoples'] contact with nature has gone, and with it has gone the profound emotional energy that this symbolic connection supplied." $\$ 4$ There is a way to restore the Great Lakes. Anishinaabe elder Eddie Benton-Benai argues that we must choose between two roads: "the road to technology and the other road to Spiritualism. ... The [other] road represents the slower path that Traditional Native people have traveled and are now seeking again. The Earth is not scorched on this trail. The grass is still growing there." 85 Our choice is before us.

84. CARL G. JUNG, MAN AND HIS SYMBOLS 95 (1964).

85. WinONa LADUKE, All OUR RELATIONS: NATIVE STRUGGLES FOR LAND AND LifE 198 (1999) (footnote omitted) (quoting Edward Benton-Benai; brackets and ellipses in original); see also EdWARD BeNTON-BeNAI, The Mishomis BoOK: THE VOICE OF THE OJiBWAY 111-12 (1979) (expanding upon the same discussion). 
HeinOnline -- 2006 Mich. St. L. Rev. 12982006 